\title{
SYNTHESIS, SPECTROSCOPIC CHARACTERIZATION, AND ANTIMICROBIAL STUDIES OF SOME N/O DONAR LIGAND COMPLEXES OF Sn(IV) DERIVED FROM ISATINO-3- BENZHYDRAZONE
}

\author{
Punit Yadav ${ }^{\circledR}$, Ramhari Meena and Bidya S. Joshi \\ Department of Chemistry, University of Rajasthan, Jaipur-302004, Rajasthan India. \\ ${ }^{\square}$ Corresponding Author: pypunityadav5@gmail.com
}

\begin{abstract}
The reaction of isatino-3-benzhydrazone(HIBZ), base and organotin(IV) chloride under anhydrous environment a series of biologically active organotin(IV) complexes of the type $\left[\mathrm{R}_{n} \mathrm{SnCl}_{3-\mathrm{n}}(\mathrm{IBZ})\right][\mathrm{R}=\mathrm{Ph}, \mathrm{n}=3 ; \mathrm{R}=\mathrm{Bu}, \mathrm{n}=3 ; \mathrm{R}=\mathrm{Bu}$, $\mathrm{n}=2 ; \mathrm{R}=\mathrm{Me}, \mathrm{n}=2$ ] were synthesized. Characterizations of all synthesized complexes were done on the principle of elemental examination and UV-VIS, FT-IR, ${ }^{1} \mathrm{H},{ }^{13} \mathrm{C}$ and ${ }^{119} \mathrm{Sn}-\mathrm{NMR}$ spectral techniques. Ligand and its organotin (IV) complexes were tested against bacteria and fungi namely Escherichia coli, Staphylococcus aureus, Aspergillus niger, and Trichoderma reesei, respectively. Some of the organotin (IV) complexes are found to possess better in vitro antibacterial and antifungal screening activity compared to the ligand.

Keywords: Antimicrobial Activities, Organotin (IV)Complexes, NMR Spectroscopy, Isatin Benzoyalhydrazones
\end{abstract}

RASĀYAN J. Chem., Vol. 14, No.2, 2021

\section{INTRODUCTION}

During the last several years, organotin(IV) complexes are among the foremost widely used organometallic species of the P-block element. ${ }^{1-5}$ and are widely employed in a range of commercial, agricultural and conjointly shows beneficial use in the pharmacological application as an antimicrobial, antitumoral, biocidal and cytotoxic agent. ${ }^{6-10}$ The presence of heteroatom such as $\mathrm{N}, \mathrm{O}$, or $\mathrm{S}$ in the ligand plays an imperative role in the geometry and so the complexes showed biological activity. ${ }^{11-12}$ These ligands are competent in coordinating to metal centers, resulting in stable chelating rings. Higher biological activities of organotin(IV) compounds encourage their applications in pharmaceutical. ${ }^{13-17}$ The isatin based mostly benzoyalhydrazones even have a large application to act as potential ligands in various metal-bound complex formation capability to coordinate to metal ion or atom either in the keto or in anionic (iminol) form via loss of 'amide' hydrogen. ${ }^{18-20}$ During this study isatinbenzoyalhydrazone ligand and its new organotin(IV) complexes were chosen to be synthesized and focus on spectral characterization and biological assessment to examine the consequence of organic group on the antimicrobial evaluation of organotin(IV) complexes.

\section{EXPERIMENTAL}

\section{Material and Methods}

Analytical grade reactants and solvents were used. Organotin precursors, liketriphenyltinchloride, tributyltinchloride, dibutyltinchloride, dimetyltinchloride was purchased from Thermo-fisher Scientific (India). Isatin and hydrazone were obtained from Sigma-Aldrich. The solvents (analytical grade) employed in the experimental work are purchased from Rankem, India, and dried before using conventional methods. All manipulations for the syntheses of complexes were executed in anhydrous conditions. Tin was estimated as tin-oxide and nitrogen were estimated as reported in the literature. ${ }^{21-22}$ Thermo scientific flash 2000 was used for elemental analysis. IR spectra $\left[4000-400 \mathrm{~cm}^{-1}\right]$ were recorded with dry KBr pellets on a SHIMADZU, FT-IR 8400 spectrometer. The data was collected on JEOL FX 300 FTNMR spectrometer in $\mathrm{CDCl}_{3}$ solution at $300.4 \mathrm{MHz}, 75.45 \mathrm{MHz}$ and $111.92 \mathrm{MHz}$ frequencies for 
${ }^{1} \mathrm{H},{ }^{13} \mathrm{C}\left\{{ }^{1} \mathrm{H}\right\}$ and ${ }^{119} \mathrm{Sn}\left\{{ }^{1} \mathrm{H}\right\}$ NMR spectra, respectively. ESI-mass spectra of complexes were obtained on Thermo Finning LCQ Advantage max ion trap spectrometer using methanol solvent.

The molecular weight was analyzed by the Beckmann thermometer. Melting points of solids were determined in sealed capillaries, and the decomposition temperatures of sticky solids were determined on a melting point block. Absorption spectra of complexes were recorded using a UV-Vis spectrophotometer from 200 to $800 \mathrm{~nm}$ range.

\section{General Procedure}

Synthesis of N'-(2-oxo-2, 3-dihydro-1H-indol-3-yl) benzohydrazide (1) (HIBZ)

Preparation of Benzohydrazide

$0.34 \mathrm{~g}$ of ethyl benzoate $(0.1 \mathrm{M})$ was added to the solution hydrazine hydrate $99 \%(0.2 \mathrm{M})$ in $\sim 20 \mathrm{ml}$ of ethanol and refluxed for $2 \mathrm{hrs}$. The resulting reaction mixture was transferred into cold water and then filtered. The solid product formed was purified with ethanol and dried in a vacuum. m.p.: $125^{\circ} \mathrm{C}$.Yield: $80 \%$.

\section{Preparation of N'-(2-oxo-2, 3-dihydro-1H-indol-3-yl) benzohydrazide (1) (HIBZ)}

A mixture of isatin $(0.01 \mathrm{M})$ and benzohydrazide, $(0.01 \mathrm{M})$ was taken in $20 \mathrm{ml}$ ethanol solvent. This mixture was traces of $\mathrm{CH}_{3} \mathrm{COOH}$ and refluxed for 3 hours. The reaction mixture was evaporated on a water bath and the residue was decanted onto packed down ice. The obtained solid product was segregated by filtration process and washed with frigid water and then dried in vacuum. M.P: $286^{\circ} \mathrm{C}$, Yield: $80 \%$.

\section{Syntheses of Organotin (IV) Complexes}

To the methanolic solution of ligand (HIBZ) N'-(2-oxo-2, 3-dihydro-1H-indol-3-yl) benzohydrazide(1.73 $\mathrm{g}, 6.55 \mathrm{mmol}), 10 \mathrm{ml}$ methanolic solution of $\mathrm{NaOH}(2 \mathrm{mmol})$ was added dropwise with constant stirring. The light yellow colour sodium salt was formed. This salt solution was refluxed under anhydrous conditions for 01 hours. This methanolic solution of the sodium salt of ligand was added to the anhydrous benzene solution of $\mathrm{Bu}_{3} \mathrm{SnCl}(6.55 \mathrm{mmol}, 2.13 \mathrm{~g})$. The colour of the reaction mixture becomes more intense. The ensuing solution was further refluxed for 6 hours under an anhydrous atmosphere. NaCI produced during reaction was filtrated and concentrated in a vacuum, which gave a dark yellow solid. This solid was purified by recrystallization with a mixture of dichloromethane and n-hexane under vacuum as a dark yellow solid. All other Sn (IV) complexes were synthesized similarly.

\section{Antimicrobial Activity}

In-vitro antibacterial activity of all the ligand (HIBZ) and Organotin (IV) complexes were studied against gram-positive Staphylococcus aureus and gram-negative Escherichia coli bacterial strains by the agar well diffusion method. ${ }^{23}$ The samples $(10 \mathrm{mg} / \mathrm{ml})$ were prepared in DMSO and further, diluted for calculating MIC value.

\section{Antifungal Activity}

The antifungal activity of all compounds was examined through the Agar Well Diffusion method. ${ }^{23}$ Sterile PBS was used to prepare suspensions of fungal spores and concentrated to $106 \mathrm{cell} / \mathrm{s} / \mathrm{ml}$. All experiments were made in triplicate and means were calculated.

\section{RESULTS AND DISCUSSION}

Organotin complexes were obtained when the reactions of $\mathrm{R}_{n} \mathrm{SnCl}_{4-n}$ with the sodium salt of hydrazone ligand (synthesized by reaction of hydrazone and freshly prepared sodium methoxide) in 1:1 molar ratio refluxing in benzene.

All the above reactions were found to be quite facile and quantitatively yielded dark yellow to brown color solids. All these metal complexes obtained as solids are found to be hygroscopic and mostly insoluble in organic solvents except DMF and DMSO. The new complexes were characterized by elemental analysis and IR and ${ }^{1} \mathrm{H},{ }^{13} \mathrm{C}$ and ${ }^{119} \mathrm{Sn}$ NMR spectroscopy. Their physical and analytical data are given in Table-1. 
RASĀYAN J. Chem.

Vol. 14 | No. 2 |1240-1246| April - June | 2021

$$
\mathrm{R}_{n} \mathrm{SnCl}_{4-\mathrm{n}}+\text { HIBZ } \underset{\mathrm{N}_{2} \text { atmosphere }}{\stackrel{\mathrm{NaOH} / \mathrm{MeOH}}{\longrightarrow}} \mathrm{R}_{\mathrm{n}} \mathrm{Sn}(\mathrm{IBZ}) \mathrm{Cl}_{3-\mathrm{n}}
$$

( where $\mathrm{n}=2,3$ or $\mathrm{R}=-\mathrm{Ph}, \mathrm{Bu}$ or $\mathrm{Me}$ )

Scheme-1

Table -1: Analytical and Physical Data of Ligand and it's Organotin (IV) Complexes

\begin{tabular}{|c|c|c|c|c|c|c|c|c|c|c|}
\hline \multirow[t]{2}{*}{ S. No. } & \multirow[t]{2}{*}{ Compound } & \multirow[t]{2}{*}{ Emp. Formula } & \multirow[t]{2}{*}{ Color } & \multirow[t]{2}{*}{ M.P } & \multicolumn{5}{|c|}{ Analysis Found (Calc)\% } & \multirow[t]{2}{*}{ Mol. Wt. } \\
\hline & & & & & C & $\mathrm{H}$ & $\mathrm{N}$ & $\mathrm{Sn}$ & $\mathrm{Cl}$ & \\
\hline 1. & HIBZ & $\mathrm{C}_{15} \mathrm{H}_{11} \mathrm{~N}_{3} \mathrm{O}_{2}$ & Orange & 286 & $\begin{array}{c}67.81 \\
(67.92)\end{array}$ & $\begin{array}{c}4.14 \\
(4.18)\end{array}$ & $\begin{array}{c}15.76 \\
(15.84)\end{array}$ & - & - & 265.27 \\
\hline 2. & $\mathrm{Ph}_{3} \mathrm{Sn}(\mathrm{IBZ})$ & $\mathrm{C}_{33} \mathrm{H}_{25} \mathrm{~N}_{3} \mathrm{O}_{2} \mathrm{Sn}$ & $\begin{array}{c}\text { Dark } \\
\text { Yellow }\end{array}$ & 200 & $\begin{array}{c}64.36 \\
(64.52)\end{array}$ & $\begin{array}{c}4.16 \\
(4.10)\end{array}$ & $\begin{array}{c}6.91 \\
(6.84)\end{array}$ & $\begin{array}{c}19.20 \\
(19.32)\end{array}$ & - & 614.29 \\
\hline 3. & $\mathrm{Bu}_{3} \mathrm{Sn}(\mathrm{IBZ})$ & $\mathrm{C}_{27} \mathrm{H}_{37} \mathrm{~N}_{3} \mathrm{O}_{2} \mathrm{Sn}$ & $\begin{array}{c}\text { Pale } \\
\text { Yellow }\end{array}$ & $>300$ & $\begin{array}{c}58.59 \\
(58.50) \\
\end{array}$ & $\begin{array}{c}6.71 \\
(6.73) \\
\end{array}$ & $\begin{array}{c}7.48 \\
(7.58) \\
\end{array}$ & $\begin{array}{l}21.30 \\
(21.42)\end{array}$ & - & 554.32 \\
\hline 4. & $\begin{array}{c}\mathrm{Bu}_{2} \mathrm{Sn}(\mathrm{IBZ}) \\
\mathrm{Cl}\end{array}$ & $\begin{array}{c}\mathrm{C}_{23} \mathrm{H}_{28} \mathrm{ClN}_{3} \mathrm{O}_{2} \mathrm{~S} \\
\mathrm{n}\end{array}$ & Brown & $>300$ & $\begin{array}{c}51.74 \\
(51.86)\end{array}$ & $\begin{array}{c}5.24 \\
(5.30)\end{array}$ & $\begin{array}{c}7.96 \\
(7.89)\end{array}$ & $\begin{array}{c}22.07 \\
(22.29)\end{array}$ & $\begin{array}{c}6.56 \\
(6.66)\end{array}$ & 532.66 \\
\hline 5. & $\begin{array}{c}\mathrm{Me}_{2} \mathrm{Sn}(\mathrm{IBZ}) \\
\mathrm{Cl}\end{array}$ & $\begin{array}{c}\mathrm{C}_{17} \mathrm{H}_{16} \mathrm{ClN}_{3} \mathrm{O}_{2} \mathrm{~S} \\
\mathrm{n}\end{array}$ & $\begin{array}{c}\text { Dark } \\
\text { Yellow }\end{array}$ & $>300$ & $\begin{array}{c}45.62 \\
(45.53)\end{array}$ & $\begin{array}{c}3.56 \\
(3.60)\end{array}$ & $\begin{array}{c}9.27 \\
(9.37)\end{array}$ & $\begin{array}{l}26.25 \\
(26.47)\end{array}$ & $\begin{array}{c}7.90 \\
(7.90)\end{array}$ & 448.0 \\
\hline
\end{tabular}

\section{IR Spectra}

The important IR spectral vibrations and their assignments of organotin complexes are revealed in Table2. These IR vibrations of all complexes have been compared with the spectrum of free ligands and their ligands derivatives. The $(\mathrm{NH})$ and $(\mathrm{C}=\mathrm{O})$ absorption bands ofthe amido group which appeared at $3233 \mathrm{~cm}^{-}$ 1 and $1624 \mathrm{~cm}^{-1}$ in the spectrum of free ligand, were not detected in the spectrum of complexes. The emergence of a new band in the IR spectrum of these complexes at 427-477 and 534-549 $\mathrm{cm}^{-1}$ region, assigned to $v(\mathrm{Sn}-\mathrm{N}), v(\mathrm{Sn}-\mathrm{O})$ also supports the coordination of $\mathrm{N}$ and $\mathrm{O}$ to the tin metal ion respectively. ${ }^{24,25}$ The new $v(\mathrm{C}=\mathrm{N})$ mode observed at $1535 \mathrm{~cm}^{-1}$ in spectra of hydrazones undergoes little shifts (1625-1632) in the spectrum of the complexes recommend that $\mathrm{N}$ atom of the ligand moiety affixed to the indole ring also coordinating to the metal ion in complexes formation. This information was supported by the emergence of a new weak-medium intensity band at $424-479 \mathrm{~cm}-1$ due to $v$ (Sn-N) stretching vibrations. ${ }^{24-25}$

The above IR spectral data is indicated that all the above-mentioned complexes Sn, the ligand appeared to bind with metal via $\mathrm{N}$ and $\mathrm{O}$ in a tridentate fashion.

Table-2: Important IR Spectral Data $\left(\mathrm{cm}^{-1}\right)$ of Ligand and its Corresponding Organotin (IV) Complexes

\begin{tabular}{|c|c|c|c|c|c|c|}
\hline Compounds & $v(\mathrm{NH})$ & $v(\mathrm{C}=\mathrm{N})$ & $v(\mathrm{C}=\mathrm{O})$ & $v(\mathrm{Sn}-\mathrm{C})$ & $v(\mathrm{Sn} \leftarrow \mathrm{N})$ & $v(\mathrm{Sn}-\mathrm{O})$ \\
\hline HIBZ & 3233 & 1535 & $\begin{array}{l}1624 \\
1693 \\
\end{array}$ & - & - & - \\
\hline $\mathrm{Ph}_{3} \mathrm{Sn}(\mathrm{IBZ})$ & - & 1530 & - & 644 & 447 & 541 \\
\hline $\mathrm{Bu}_{3} \mathrm{Sn}(\mathrm{IBZ})$ & - & 1527 & - & 625 & 427 & 549 \\
\hline $\mathrm{Bu}_{2} \mathrm{Sn}(\mathrm{IBZ}) \mathrm{Cl}$ & - & 1529 & - & 635 & 429 & 547 \\
\hline $\mathrm{Me}_{2} \mathrm{Sn}(\mathrm{IBZ}) \mathrm{Cl}$ & - & 1532 & - & 640 & 477 & 534 \\
\hline
\end{tabular}

\section{${ }^{1} \mathrm{H}$ NMR Spectra}

The expected NMR spectral information of ligand and their metal complexes are depicted in Table-3. However, in some cases due to the less solubility of complexes in $\mathrm{CDCl}_{3}$, the ${ }^{13} \mathrm{CNMR}$ spectra could not be resolved. These data were made by the comparison of the spectrum of free ligand and other related organotin complexes, and corroborate the results observed from the IR spectral studies. The signal appeared at $\delta 11.2 \mathrm{ppm}$ due to $-\mathrm{NH}$ proton in free ligand spectrum, was absent in spectra of all these complexes, suggested that deportation took place during the complexation and ligand attached to the $\mathrm{Sn}$ in 
RASĀYAN J. Chem.

Vol. 14 | No. 2 |1240-1246| April - June | 2021

anionic and neutral form. The other protons of ligand moiety like aromatic protons appeared as a multiple in the region $\delta 6.8-8.0 \mathrm{ppm}$ in the spectrum of complexes and almost the same as ligand. In all the tin complexes, another proton resonance of the organic moiety attached to the Sn metal appeared at the expected position with desirable multiplicities (Table-3).

Table- $3:{ }^{1} \mathrm{H}$ NMR Spectral Data of the Ligand and its Corresponding Organotin (IV) Complexes

\begin{tabular}{c|c|c|c|c|c}
\hline \multirow{2}{*}{ Compounds } & \multicolumn{5}{|c}{ Chemical Shift $(\delta \mathrm{ppm})$} \\
\cline { 2 - 6 } & $-\mathrm{NH}$ & Aromatic & $\mathrm{Sn}-\mathrm{Bu}$ & Sn-Me & Sn-Ph \\
\hline $\mathrm{HIBZ}$ & $\begin{array}{c}14(\mathrm{~s}, 1 \mathrm{H}) \\
11.2(\mathrm{~s}, 1 \mathrm{H})\end{array}$ & $6.8-8.0(\mathrm{~m}, 9 \mathrm{H})$ & - & - & - \\
\hline $\mathrm{Ph}_{3} \mathrm{Sn}(\mathrm{IBZ})$ & $14(\mathrm{~s}, 1 \mathrm{H})$ & $7.2-7.8(\mathrm{~m}, 9 \mathrm{H})$ & - & - & $\begin{array}{c}7.2-8.0 \\
(\mathrm{~m}, 15 \mathrm{H})\end{array}$ \\
\hline $\mathrm{Bu}_{3} \mathrm{Sn}(\mathrm{IBZ})$ & $14(\mathrm{~s}, 1 \mathrm{H})$ & $6.5-7.8(\mathrm{~m}, 9 \mathrm{H})$ & $\begin{array}{c}0.70-1.46 \\
(\mathrm{~m}, 27 \mathrm{H})\end{array}$ & - & - \\
\hline $\mathrm{Bu}_{2} \mathrm{Sn}(\mathrm{IBZ}) \mathrm{Cl}$ & $14(\mathrm{~s}, 1 \mathrm{H})$ & $6.5-8.0(\mathrm{~m}, 9 \mathrm{~h})$ & $\begin{array}{c}0.94-1.4 \\
(\mathrm{~m}, 18 \mathrm{H})\end{array}$ & - & - \\
\hline $\mathrm{Me}_{2} \mathrm{Sn}(\mathrm{IBZ}) \mathrm{Cl}$ & $14(\mathrm{~s}, 1 \mathrm{H})$ & $6.8-8.2(\mathrm{~m}, 9 \mathrm{H})$ & - & $1.14(\mathrm{~s}, 1 \mathrm{H})$ & - \\
\hline
\end{tabular}

Chemical shift $(\delta)$ ppm. Multiplicity is given as: $\mathrm{s}=$ singlet, $\mathrm{d}=$ doublet, $\mathrm{t}=$ triplet, $\mathrm{q}=$ quartet, $\mathrm{m}=$ complex pattern

\section{${ }^{13} \mathrm{C}$ NMR and ${ }^{119}$ Sn NMR}

The ${ }^{13} \mathrm{C}\left\{{ }^{1} \mathrm{H}\right\}$ and ${ }^{119} \mathrm{Sn}\left\{{ }^{1} \mathrm{H}\right\}$-NMR spectral data of organotin complexes are revealed in table 4. The chemical shift assessment of $\mathrm{C}=\mathrm{N}$ and $\mathrm{C}-\mathrm{O}$ in ${ }^{13} \mathrm{C}$ NMR spectra of complexes that appeared in the region $\delta$ 144.50-139.14 and 169.98-163.06 indicate the creation of $\mathrm{Sn}-\mathrm{N}$ and $\mathrm{Sn}-\mathrm{O}$ bond, respectively. In ${ }^{13} \mathrm{CNMR}$ spectrum of all the organotin derivatives, all signals for alkyl and aryl groups are observed at the expected regions.

The ${ }^{119} \mathrm{Sn}\left\{{ }^{1} \mathrm{H}\right\}$-NMR spectrum of $(\mathrm{Ph})_{3} \mathrm{Sn}(\mathrm{IBZ})$ complex displayed a sharp single resonance in the region $\delta 226.24 \mathrm{ppm} .{ }^{119} \mathrm{Sn}$ NMR signals for $(\mathrm{Ph})_{3} \mathrm{SnCl}_{2}$ appear at $\delta-32 \mathrm{ppm} .{ }^{26}$ Based on these observed chemical shift difference, it is assumed that the coordination number of $\mathrm{Sn}$ in this complex is six. ${ }^{27}$

\section{UV Spectra}

The UV-Vis absorption spectra of the above free ligand (HIBZ) and their Sn complexes (1-4) were recorded in methanol solution against ligands blank in the wavelength range 200-800 nm (Fig.-1). The ligand (HIBZ) showed two absorptions at 327 and $248 \mathrm{~nm}$ in Fig.-1. The absorption at 248 is owing to the $\pi-\pi^{*}$ transitions of the aromatic regions while at $327 \mathrm{~nm}$ were assigned due to the $\mathrm{n}-\pi^{*}$ transition of the $\mathrm{C}=\mathrm{N}$ or $\mathrm{C}-\mathrm{O}$ groups. It is supported by literature and related to the $\pi-\pi^{*}$ transitions of the aromatic rings. ${ }^{28}$

A small shift in the absorption bands of the complexes compared to the ligand in the spectra is owing to the interaction of ligand to metal transitions. There is considerable shifting in the $\mathrm{C}=\mathrm{N}$ or $\mathrm{C}-\mathrm{O}$ due to coordination with tin. ${ }^{29}$ Consequently, the shift in the absorption bands reveals coordination between ligand and tin (IV).

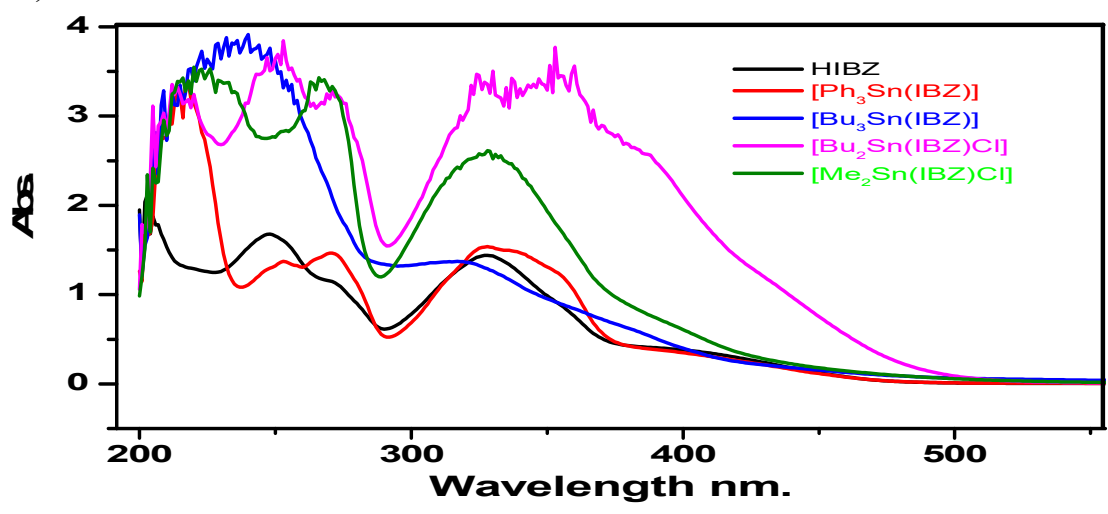

Fig.-1: Absorption Spectra of Ligands and their Complexes (against Ligands) 
RASĀYAN J. Chem.

Vol. 14 | No. 2 |1240-1246| April - June | 2021

Efforts to obtain good quality crystals of complexes were unsuccessful. In absence of crystal structures, it is intricate to comment on the solid-state structure of the complexes. Nevertheless, the above studies do indicate the possibility of the following structures (Fig.-2).

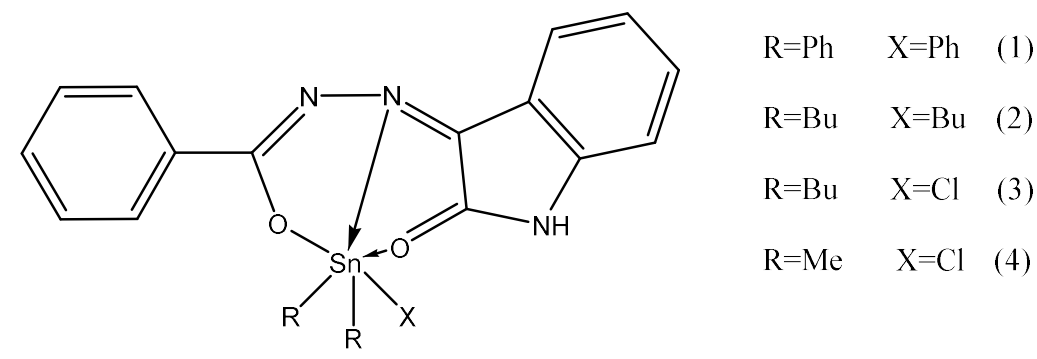

Fig.-2: The Proposed Structure of Metal Complexes

Table- 4: ${ }^{13} \mathrm{C}$ and ${ }^{119} \mathrm{Sn}$ NMR Spectral Data of the Ligand and its corresponding Organotin (IV) Complexes

\begin{tabular}{c|c|c|c|c|c|c|c}
\hline \multirow{2}{*}{ Compounds } & \multicolumn{7}{|c}{ Chemical Shift $(\delta \mathrm{ppm})$} \\
\cline { 2 - 8 } & ${ }^{119} \mathrm{Sn}$ & $-\mathrm{NH}-\mathrm{C}=\mathrm{O}$ & $>\mathrm{C}=\mathrm{N}$ & Aromatic & $\mathrm{Sn}-\mathrm{Bu}$ & $\mathrm{Sn}-\mathrm{Me}$ & $\mathrm{Sn}-\mathrm{Ph}$ \\
\hline \multirow{2}{*}{$\mathrm{HIBZ}$} & - & $\begin{array}{c}163.06 \\
165.10\end{array}$ & $\begin{array}{c}144.50 \\
143.00\end{array}$ & $\begin{array}{c}133.43- \\
111.19\end{array}$ & - & - & - \\
\hline $\mathrm{Ph}_{3} \mathrm{Sn}(\mathrm{IBZ})$ & -226.24 & 163.60 & 143.01 & $\begin{array}{c}129.72- \\
111.78\end{array}$ & - & - & $\begin{array}{c}136.54- \\
132.38\end{array}$ \\
\hline $\mathrm{Bu}_{3} \mathrm{Sn}(\mathrm{IBZ})$ & - & 169.98 & 142.50 & $\begin{array}{c}129.50- \\
127.67\end{array}$ & $\begin{array}{c}14.13- \\
28.35\end{array}$ & - & - \\
\hline $\mathrm{Bu}_{2} \mathrm{Sn}(\mathrm{IBZ}) \mathrm{Cl}$ & - & 163.60 & 143.01 & $\begin{array}{c}133.43- \\
111.78\end{array}$ & $\begin{array}{c}14.06- \\
27.41\end{array}$ & - & - \\
\hline $\mathrm{Me}_{2} \mathrm{Sn}(\mathrm{IBZ}) \mathrm{Cl}$ & - & \multirow{2}{*}{163.28} & 139.14 & $\begin{array}{c}129.90- \\
110.50\end{array}$ & - & 21.40 & - \\
\hline
\end{tabular}

\section{Antimicrobial Activity of Organotin (IV) Complexes}

Antimicrobial activity of the new ligand and their organotin complexes were investigated against two bacteria and two fungus, $S$. aureus $\left(\mathrm{G}^{+}\right) \& E$. coli $\left(\mathrm{G}^{-}\right)$and fungal T. reesei $\left(\mathrm{G}^{+}\right)$and A.niger $\left(\mathrm{G}^{-}\right)$, respectably. The results of the Antimicrobial activity are revealed in Table-5 and Figs. -3 and 4.

The ligand HIBZ did not show any anti-bacterial as well as antifungal activity against the tested microorganisms like $S$. aureus $\left(\mathrm{G}^{+}\right)$and A.niger $\left(\mathrm{G}^{-}\right)$while it shows activity against E. coli $\left(\mathrm{G}^{-}\right)$and $T$. reesei $\left(\mathrm{G}^{+}\right)$. Higher anti-microbial activity of ligand complexes is because of the consequence of metal ions on the normal cell processes. An apparent mode for the activity raise may be measured in the light of Tweedy's-Chelation theory. ${ }^{30}$ Chelation significantly reduced the polarity of metal ions owing to the fractional allocation of its +ve charge with donor groups and the $\pi$-electron delocalization over the complete chelate ring. Such chelation could increase the lipophilic nature of the central metal atom, which favors its permeation through the lipid layer of the cell membrane.

As shown in Table-5 all organotin complexes were observed significant activity against all the screened microorganisms and fungi but complexes $\mathrm{Bu}_{2} \mathrm{Sn}(\mathrm{IBZ}) \mathrm{Cl}$ ) and $\mathrm{Bu}_{3} \mathrm{Sn}(\mathrm{IBZ})$ do not show any bacterial and fungal growth against tested microorganisms and fungi, S. aureus and A. Niger, respectively.

Table-5: Antibacterial Activity Data for Ligands and their Anionic Complexes after 24 hours.

\begin{tabular}{c|c|c|c|c|c}
\hline \multirow{2}{*}{ Compound } & $\begin{array}{c}\text { Concentration } \\
(\mathrm{mg} / \mathrm{Disc})\end{array}$ & $\begin{array}{c}\text { Average Value of Bacteriostatic } \\
\text { Diameter }(\mathrm{mm})^{*}\end{array}$ & \multicolumn{2}{c}{$\begin{array}{c}\text { Average Value of Fungal } \\
\text { Static Diameter (mm)* }\end{array}$} \\
\cline { 3 - 6 } & & S. aureus & E. coli & T. reesei & A.niger \\
\hline Standard & 1 & 22 & 21 & 20 & 20 \\
\hline $\mathrm{HIBZ}$ & 1 & 0 & 12 & 15 & - \\
\hline $\mathrm{Ph}_{3} \mathrm{Sn}(\mathrm{IBZ})$ & 1 & 15 & 19 & 21 & 22 \\
\hline $\mathrm{Bu}_{3} \mathrm{Sn}(\mathrm{IBZ})$ & 1 & 27 & 25 & 26 & - \\
\hline $\mathrm{Bu}_{2} \mathrm{Sn}(\mathrm{IBZ}) \mathrm{Cl}$ & 1 & 0 & 20 & 22 & 22 \\
\hline $\mathrm{Me}_{2} \mathrm{Sn}(\mathrm{IBZ}) \mathrm{Cl}$ & 1 & 35 & 24 & 25 & 23 \\
\hline
\end{tabular}

Agar well diffusion method (in vitro) $=1.0 \mathrm{mg} \mathrm{mL}^{-1}$;Reference drug =Ciprofloxacin (for bacteria) Inhibition zone $22 \mathrm{~mm}$, Ketokenazole (for fungi) - Inhibition zone-20mm. * Standard. 
RASĀYAN J. Chem.

Vol. 14 | No. 2 |1240-1246| April - June | 2021

In general complexes $\mathrm{Me}_{2} \mathrm{Sn}(\mathrm{IBZ}) \mathrm{Cl}$ showed high activity against all $\mathrm{G}^{-}$or $\mathrm{G}+$ bacteria and fungi. This effect indicates that the methylorganotin complex is highly active compared to the other organotin complexes. Complexes $\mathrm{Me}_{2} \mathrm{Sn}(\mathrm{IBZ}) \mathrm{Cl}$ and $\mathrm{Bu}_{2} \mathrm{Sn}(\mathrm{IBZ}) \mathrm{Cl}$ ) were shown the most potent activity than the standard for both the bacteria and fungi as shown in the table. The result shows that all organotin complexes showed enhanced antimicrobial activity as compared to the parent ligands.

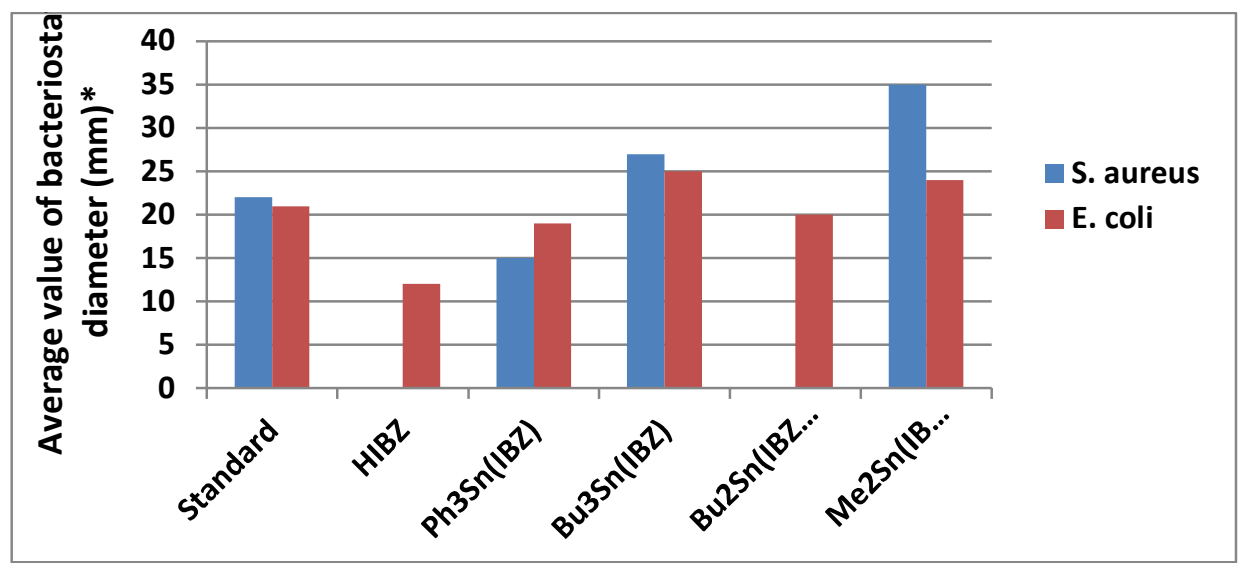

Fig.-3: Bar Graph showing the relative Antibacterial Activity of the Ligands and their Complexes

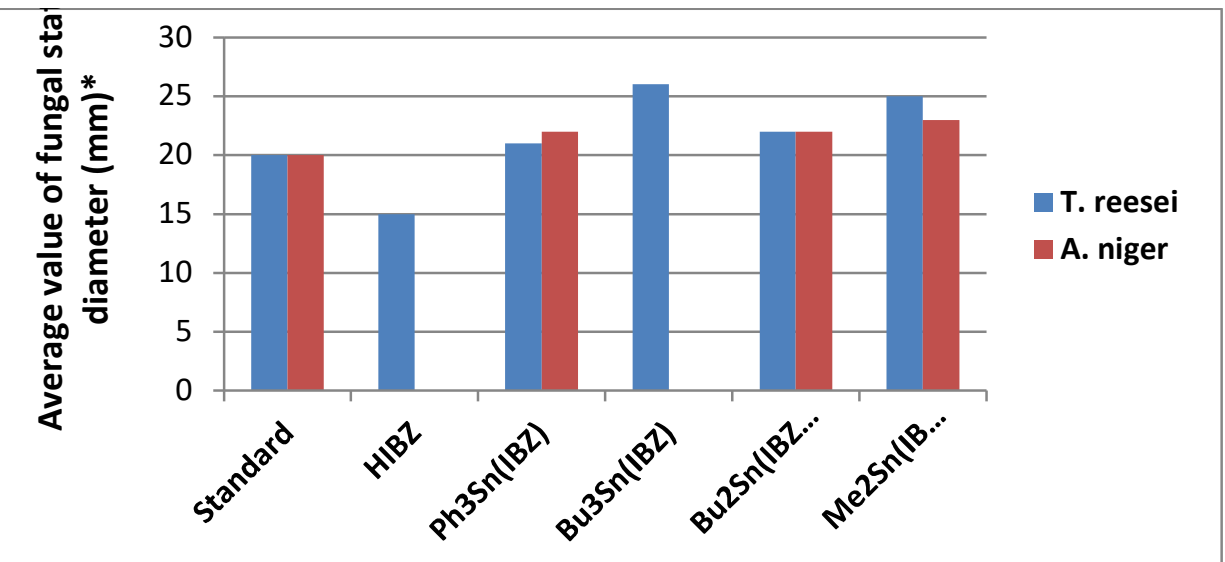

Fig.-4: Bar Graph showing the relative Antifungal Activity of the Ligands and their Complexes

\section{CONCLUSION}

The four new organotin complexes with hydazone ligand were synthesized and characterized through elemental analyses, MS, IR and NMR spectral data. Monofunctional tridentate behaviour of hydrazone ligand was suggested based on spectral data. ${ }^{1} \mathrm{H},{ }^{13} \mathrm{C}$ and ${ }^{119} \mathrm{Sn}-\mathrm{NMR}$ values support the hexa coordinated to tin atom. The metal complexes appeared more potent activity than the corresponding ligand because of antimicrobial activities, and the activity affected the group attached to the Sn atom.

\section{ACKNOWLEDGEMENT}

The authors are thankful to the Head, Department of Chemistry, for providing the necessary research facilities. This study received financial assistance from the University of Rajasthan, Jaipur during the research work. We are also thankful to USIC (University Science Instrumentation Centre) and MNIT Jaipur for providing analytical and spectral data.

\section{REFERENCES}

1. M. Nath and P. K. Saini, Dalton Transaction, 40, 7077(2011), DOI:10.1039/C0DT01426E

2. M. A. Salam, A. Alam, S. Sarker and Mohammed M. Rahman, Journal of Coordination Chemistry, 71, 1593(2018), DOI:10.1080/00958972.2018.1468888

3. A.G. Davies and P. J. Smith, Advances in Inorganic Chemistry and Radiochemistry, 77, 1(1980), DOI: $10.1016 / \mathrm{S} 0065-2792(08) 60091-6$ 
RASĀYAN J. Chem.

Vol. 14 | No. 2 |1240-1246| April - June | 2021

4. I.A. Ahmed, G. Kastner, H. Reuter and D. Schultze, Journal of Organomettalic Chemistry ,659, 147(2002).

5. N. Rabiee, M. Safarkhani and M. M. Amini, Reviews in Inorganic Chemistry, 14 (2018), DOI: $10.1515 /$ revic-2018-0014

6. M. Gielen, Applied Organometallic Chemistry, 16, 481 (2002), DOI:10.1002/aoc.331

7. S. K. Hadjikakou and N. Hadjiliadis, Coordination Chemistry Reviews, 253, 235(2009), DOI:10.1016/j.ccr.2007.12.026

8. D. Tzimopoulos, I. Sanidas and A.C. Varvogli, Journal of Inorganic Biochemistry, 104(4), 423(2010), DOI: 0.1016/j.jinorgbio.2009.12.006 424

9. Linniu, Yunlanli and Qingshan Li, Inorganica Chimica Acta, Part B, 423, 2(2014), DOI:10.1016/j.ica.2014.05.007

10. T.S. Basu Baul, Applied Organometallic Chemistry, 195(2008), DOI:10.1002/aoc.1378

11. A.G. Davies and P. J. Smith, Advances in Inorganic Chemistry and Radiochemistry, 23,1(1980). DOI: 10.1016/S0065-2792(08)60091-6

12. T. Lochhart and F. Davidson, Organometallics ,6, 2471(1987), DOI:10.1021/om00155a002

13. J.A. Crowe, Springer-verlag Berlin Heidelberg, 37(H), 69 (1990), DOI:10.1007/978-94-011-12529 . 7

14. S. S. Shah, M. Ashfaq, A. Waseem, M.M. Ahemad, T. Najam, S. Shaheen and G. Rivera, Reviews in Medicinal Chemistry, 15(5), 406(2015), DOI:10.2174/138955751505150408142958

15. A. G. Hadi, K. Jawad, D. S. Ahmed and E. Yousif, Systamatic Reviews in Pharmacy, 10(1), 26(2019), DOI:10.5530/srp.2019.1.5

16. M. Nath, M. Vats and P. Roy, European Journal of Medicinal Chemistry, 59, 310(2013), DOI: $10.1016 /$ j.ejmech.2012.11.023

17. M. Nath, M. Vats and P. Roy, Journal of Photochemistry and Photobiology B: Biology, 148, 88(2015), DOI:10.1016/j.jphotobiol.2015.03.034

18. R. B. N. Bessy, M. R. P. Kurup and E. Suresh, Structural Chemistry, 17, 206(2006), DOI: $10.1007 / \mathrm{s} 11224-006-9012-6$

19. H.S Saleem and M.A. Mousa, Chemistry Central Journal, 5(47), 1(2011), DOI:10.1186/1752-153X5-47

20. L. N. Suvarapui, Y.K. Seo, S. Baek, V. Reddy and A. Reddy, E-Journal of Chemistry, 9(3), 1288(2012), DOI: 10.1155/2012/534617

21. S. Agarwal, V. Sharma and R. Bohra, Journal of Chemical Research, 7, 426(2006), DOI:10.3184/ 030823406777980655

22. A. I. Vogel, Text book of quantitative chemical analysis, $5^{\text {th }}$ edn. Longman, London(1987).

23. A. Rahman, M.I. Choudhry and W.J. Thomsen, Bioassay Techniques for Drug Development, Harwood Academic Publishers, The Netherlands, 65(7),1086(2002), DOI:10.1021/np020725b

24. M. K. Atal, R. Sharma, A. Saini, V. Dhayal and M. Nagar, Journal of Sol-Gel Science and Technology, 79, 114(2006)

25. V. Sharma, S. Agrawal, R. Bohra, R. Ratnani, J. E. Drake, A. L. Bingham, M. B. Hursthouse and M. E. Light, Inorganica Chimica Acta, 359 (5), 1404(2006), DOI:10.1016/j.ica.2005.09.017

26. J. Graudo, N. L. Speziali, A. Abras, M. Honer and C. Filgueiras , Polyhedron, 18, 2483(1999), DOI: 10.1016/S0277-5387(99)00123-0

27. J. S. Casas, A. Sanchez, J. Sordo, A. V. Lopez, E. E. Castellano, Z. Schpector, M. C. R. Arguelles and U. Russo, Inorganica Chimica Acta, 216,169(1994), DOI:10.1016/0020-1693(93)03724-O

28. M. A. Salam, M. Alam, S. Sarker and M. M. Rahman, Journal of Coordination Chemistry, 71(10), 1(2018), DOI: 10.1080/00958972.2018.1468888

29. F. F. Costa, A. P. Rebolledo, T. Matencio, H. D. R. Calado, J. D. Ardisson, M. E. Cortes, B. L. Rodrigues and H. Beraldo, Journal of Coordination Chemistry, 58, 1307(2005), DOI: $10.1080 / 00958970500213307$

30. B.G. Tweedy, Phytopathology, 55, 910 (1964).

[RJC-6168/2020] 